\title{
Photocytotoxicity of a 5-nitrofuran- ethenyl-quinoline antiseptic (Quinifuryl) to P388 mouse leukemia cells
}

\section{N.A. Daghastanli ${ }^{1}$, \\ I.A. Degterev ${ }^{1,3}$, \\ A.C. Tedesco ${ }^{2}$ and \\ I.E. Borissevitch ${ }^{1}$}

\begin{abstract}
Departamentos de ${ }^{1}$ Física e Matemática, and ${ }^{2}$ Química, Faculdade de Filosofia, Ciências e Letras de Ribeirão Preto, Universidade de São Paulo, Ribeirão Preto, $\mathrm{SP}$, Brasil

${ }^{3}$ Department of Chemical and Biological Kinetics, Institute of Biochemical Physics, Russian Academy of Sciences, Moscow, Russian Federation
\end{abstract}

Correspondence

I.E. Borissevitch

Departamento de Física e Matemática FFCLRP, USP

Av. Bandeirantes, 3900

14040-901 Ribeirão Preto, SP

Brasil

Fax: +55-16-633-9949

E-mail: iouribor@usp.bror

iourib@ffclrp.usp.br

Research supported by FAPESP and CAPES

Received April 22, 2004 Accepted August 12, 2004

\begin{abstract}
Quinifuryl (MW 449.52), 2-(5'-nitro-2'-furanyl)ethenyl-4-\{N-[4'-(N,Ndiethylamino)-1'-methylbutyl]carbamoyl $\}$ quinoline, is a water soluble representative of a family of 5-nitrofuran-ethenyl-quinoline drugs which has been shown to be highly toxic to various lines of transformed cells in the dark. In the present study, the toxicity of Quinifuryl to P388 mouse leukemia cells was compared in the dark and under illumination with visible light (390-500 nm). Illumination of water solutions of Quinifuryl (at concentrations ranging from 0.09 to $9.0 \mu \mathrm{g} /$ $\mathrm{ml}$ ) in the presence of P388 cells resulted in its photodecomposition and was accompanied by elevated cytotoxicity. A significant capacity to kill P388 cells was detected at a drug concentration as low as 0.09 $\mu \mathrm{g} / \mathrm{ml}$. The toxic effect detected at this drug concentration under illumination exceeded the effect observed in the dark by more than three times. Moreover, the general toxic effect of Quinifuryl, which included cell proliferation arrest, was nearly $100 \%$. Both dose- and time-dependent toxic effects were measured under illumination. The $\mathrm{LC}_{50}$ value of Quinifuryl during incubation with P388 cells was $\sim 0.45$ $\mu \mathrm{g} / \mathrm{ml}$ under illumination for $60 \mathrm{~min}$ and $>12 \mu \mathrm{g} / \mathrm{ml}$ in the dark. We have demonstrated that the final products of the Quinifuryl photolysis are not toxic, which means that the short-lived intermediates of Quinifuryl photodecomposition are responsible for the phototoxicity of this compound. The data obtained in the present study are the first to indicate photocytotoxicity of a nitroheterocyclic compound and demonstrate the possibility of its application as a photosensitizer drug for photochemotherapy.
\end{abstract}

\section{Introduction}

Photochemotherapy, and photodynamic therapy in particular $(1,2)$, are relatively new approaches to the treatment of various diseases, including cancer. An extensive search for new photochemotherapy agents contin-
Key words

- Phototoxicity

- Nitrofurane derivatives

- Quinifuryl

- Oxygen and nitrogen active species 
ences, Riga, Latvia, with the aim of developing new antitumor agents. These compounds have shown significant toxicity to various lines of cancer cells $(10,11)$, with Quinifuryl possessing the highest cytotoxic activity (10) and showing radiosensitizing activity in vitro (12).

Quinifuryl absorbs light in the visible spectral region owing to the presence of a developed system of $\pi$-conjugation that makes it photolabile under irradiation in this spectral region. The excited singlet state is the first product of photoexcitation and may either decompose or form the excited triplet state (13). The latter reacts with either an electron donor, including another molecule of Quinifuryl in the ground state, or transfers its excitation energy to molecular oxygen (13). Illumination of a system containing the drug should therefore result in a decrease of Quinifuryl concentration and the formation of new compounds resulting from its phototransformation. Thus, the effect of illumination on Quinifuryl cytotoxicity is unpredictable because the products of phototransformation may be more or less toxic to transformed cells than Quinifuryl itself.

In the present study, the cytotoxicity of Quinifuryl to mouse leukemia P388 cells was compared in the dark and under continuous illumination with light in the spectral region from 390 to $500 \mathrm{~nm}$.

\section{Material and Methods}

\section{Cells}

A mouse macrophage monocyte line, $\mathrm{P} 388 \mathrm{D}_{1}$, that grows in semi-suspension cul-

Figure 1. Structure of Quinifuryl, 2-(5'-nitro-2'-furanyl)ethenyl-4$\left\{\mathrm{N}-\left[4^{\prime}-(\mathrm{N}, \mathrm{N}-\right.\right.$ diethylamino $)-1^{\prime}$ methylbutyl]carbamoyl\} quinoline. ture was obtained from the American Type Culture Collection (No. CCL46). Cells were grown in Fisher's medium supplemented with $10 \%$ heat-inactivated horse serum in 175 $\mathrm{cm}^{3}$ culture flasks at $37^{\circ} \mathrm{C}$ with $5 \% \mathrm{CO}_{2}$. On the day before the experiment, cells were seeded at $5 \times 10^{5}$ cells $/ \mathrm{ml}$. The number of cells in suspension was calculated using a Neubauer chamber $\left(0.0025 \mathrm{~mm}^{2}\right)$. Slow magnetic stirring was used to maintain the suspension in a homogeneous state. All manipulations were carried out under low intensity red light $(\lambda>550 \mathrm{~nm})$ at room temperature $\left(22^{\circ} \mathrm{C}\right)$.

\section{Drug}

A stock solution of $43.0 \mathrm{mM}$ Quinifuryl, 2-(5'-nitro-2'-furanyl)ethenyl-4- $\{\mathrm{N}-[4$ - $-(\mathrm{N}, \mathrm{N}-$ diethylamino)-1'-methylbutyl]carbamoyl quinoline (Figure 1), was prepared in MilliQ quality water (Millipore).

\section{Tests}

The cell survival test (test 1) was based on the method of intravitral staining (14) using Trypan blue (TB) as a dye to which the living cell is impermeable (15). The number of dead P388 cells was counted using a Neubauer chamber $\left(0.0025 \mathrm{~mm}^{2}\right)$ with $10 \mu \mathrm{l}$ of TB added to $90-\mu \mathrm{l}$ aliquots of a cell suspension withdrawn consecutively from the sample or control mixtures after appropriate time intervals. This test was employed for the comparative examination of the cytotoxicity of Quinifuryl in the dark and of the final products of its photodecomposition to P388 cells.

The toxicity test was based on the tetra-

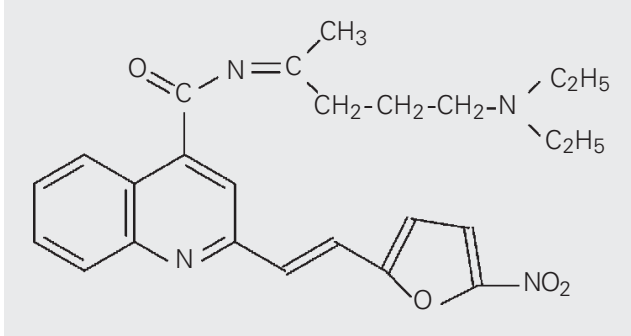
zolium salt 3-(4,5-dimethylthiazol-2-yl)-2-5 diphenyl tetrazolium bromide (MTT) assay and was performed in two ways as described previously (11) and designated here as tests 2 and 3. MTT is reduced only by live cells to yield a colored product that may be interpreted as a measure of viability (16). For the 
MTT assay, cells were seeded in DMEM containing 5\% FBS into 96-well ELISAtype plates and exposed to Quinifuryl concentrations ranging from 0.2 to $20 \mu \mathrm{M}$ for time intervals of $60 \mathrm{~min}$ in the dark or of 10 to $90 \mathrm{~min}$ in the presence of illumination. At the end of the drug exposure periods, plates were centrifuged to pellet the cells and the supernatants were displaced with either MTT dissolved in PBS (test 2) or with fresh medium (test 3 ). In the latter case, the cells were incubated for an additional $52 \mathrm{~h}$ ( 2 cell population-doubling times) with daily medium changes, followed by the MTT assay. Plates with MTT were incubated in the dark for $4 \mathrm{~h}$, after which the water-insoluble MTT-formazan crystals were dissolved in DMSO, and the absorbance was determined with an ELISA plate reader Dynex MRX spectrophotometer (Dynex Technologies Inc., Chantilli, VA, USA) at $570 \mathrm{~nm}$. The initial seeding densities ranged from $2 \times 10^{4}$ to $6 \mathrm{x}$ $10^{4}$ cells/well. Cell viability was assessed by TB dye exclusion at the beginning of each experiment and was always greater than $96 \%$.

\section{Irradiation}

Samples and controls were irradiated in the spectral range from 390 to $500 \mathrm{~nm}$ using a standard tungsten lamp $(150 \mathrm{~W})$ through a colored glass filter 5-57 KOPP (Dieburg, Germany). Irradiation was performed either in a standard quartz 1 -cm cuvette (test 1 ) or directly in ELISA-type plates (tests 2 and 3 ). The illumination intensity was $22 \mathrm{~mW} / \mathrm{cm}^{2}$, as measured with a Spectra-Physics 407A radiometer. A standard 1-cm quartz cuvette with water was used as a thermal filter to prevent collateral heating effects. Absorbance was monitored using a DU 650 Beckman spectrophotometer (Fullerton, CA, USA).

The protocol for the Quinifuryl photocytotoxicity studies is summarized in Table 1 and is described as follows: a) sample (S): Quinifuryl was added to a cell suspension and the mixture was immediately irradiated for time intervals up to $60 \mathrm{~min}$; b) control 1 (C1) - the cell suspension was maintained in phosphate buffer for $\geq 60 \mathrm{~min}$ in the dark and in the absence of Quinifuryl; c) control 2 (C2) - the cell suspension was incubated for $\geq 60 \mathrm{~min}$ in the presence of Quinifuryl in the dark; d) control 3 (C3) - the cell suspension was irradiated for $\geq 40 \mathrm{~min}$ in the absence of Quinifuryl. This series of experiments was repeated six times.

\section{Calculation and statistical analysis}

The toxic effect (TE) of Quinifuryl was calculated as TE $=[\mathrm{DC}] /[\mathrm{Cell}]^{\text {control }}$, where $[\mathrm{Cell}]^{\text {control }}$ is the cell concentration in control wells (cells incubated for the same period of time without the drug) and [DC] is the dead cell concentration. [DC] is calculated as $[\mathrm{Cell}]^{\text {control }}-[\mathrm{Cell}]^{\text {final }}$, where $[\mathrm{Cell}]^{\text {final }}$ is the live cell concentration in wells exposed to the drug (5). The cell concentration was measured using a calibration curve constructed for P388 cells by the MTT-staining method.

The $\mathrm{LC}_{50}$ of Quinifuryl was estimated as $100 \times\left(\mathrm{T}^{0}-\mathrm{T}\right) / \mathrm{T}^{0}=50$, where $\mathrm{T}^{0}$ and $\mathrm{T}$ are the absorbances of the test well at time zero (when the drug is added) and after exposure to the test compound (17), respectively. The data are presented as the mean \pm SD of 6 measurements, and statistical analyses were

\begin{tabular}{lcccc} 
Table 1. Protocol for the study of Quinifuryl photocytotoxicity. \\
\hline Group & $\begin{array}{l}\text { Irradiation } \\
\text { time (min) }\end{array}$ & $\begin{array}{c}\text { Incubation } \\
\text { time (min) }\end{array}$ & $\begin{array}{c}\text { Post-incubation } \\
\text { time (h) }\end{array}$ & $\begin{array}{c}\text { Quinifuryl } \\
\text { ( } \mu \mathrm{M})\end{array}$ \\
\hline S1 Sample, test 1 & 0 to 60 & 0 to 60 & No & 20 \\
S2 Sample, test 2 & 0 to 90 & 0 to 90 & No & $0.2 ; 2 ; 20$ \\
S3 Sample, test 3 & 60 & 60 & 52 & $0.2 ; 2 ; 20$ \\
S4 Sample, test 3 & 0 & 60 & 52 & $0.2 ; 2 ; 20$ \\
C1 Control & 0 & 0 to 60 & No & No \\
C2 Control & 0 to 60 & 0 & No & $0.2 ; 2 ; 20$ \\
C3 Control & 0 to 40 & 0 & No & No
\end{tabular}

For details of S1-S4 samples and C1-C3 controls, see Material and Methods. *Time of cell incubation with Quinifuryl. 


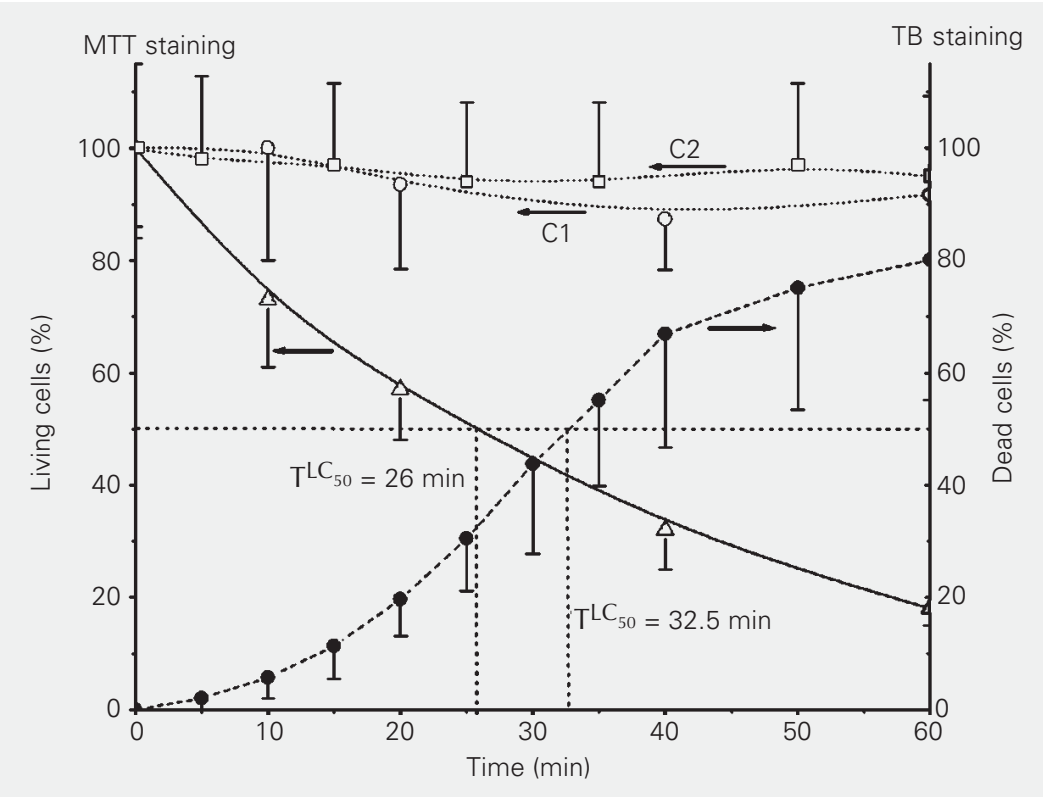

Figure 2. Photocytotoxicity of Quinifuryl $(20 \mu \mathrm{M})$ to mouse leukemia P388 cells measured by methods of dye exclusion (Trypan blue (TB), dead cells; open circles) or dye inclusion (3(4,5-dimethylthiazol-2-yl)-2-5 diphenyl tetrazolium bromide (MTT), living cells, triangles). Controls: C1 - cells incubated with Quinifuryl in the dark (closed circles) and C2 - cells illuminated for the time intervals indicated in the absence of Quinifuryl (squares). Cell concentration was $\sim 1 \times 10^{6} / \mathrm{ml}$ in sodium phosphate buffer, $\mathrm{pH} 7.4$. $\mathrm{TLC}_{50}$ is the irradiation time that was necessary to kill $50 \%$ of cells at $20 \mu \mathrm{M}$ Quinifuryl. For the other experimental conditions, see Material and Methods.

Figure 3. Photodecomposition of Quinifuryl under illumination with filtered light in the visible region. A, Spectral changes showing photobleaching of Quinifuryl $(20 \mu \mathrm{M})$ in the presence of P388 cells. The arrow shows the direction of spectral changes. Numbers show the time of illumination in min. The dashed line shows the spectrum of glass filter absorption. $B$, Dynamics of Quinifuryl photobleaching at $\lambda_{\max }=396 \mathrm{~nm}$ (arrow, A) in the absence (circles) and presence (triangles) of P388 cells. Conditions of illumination and measurements of spectra were the same as described in the legend to Figure 2.

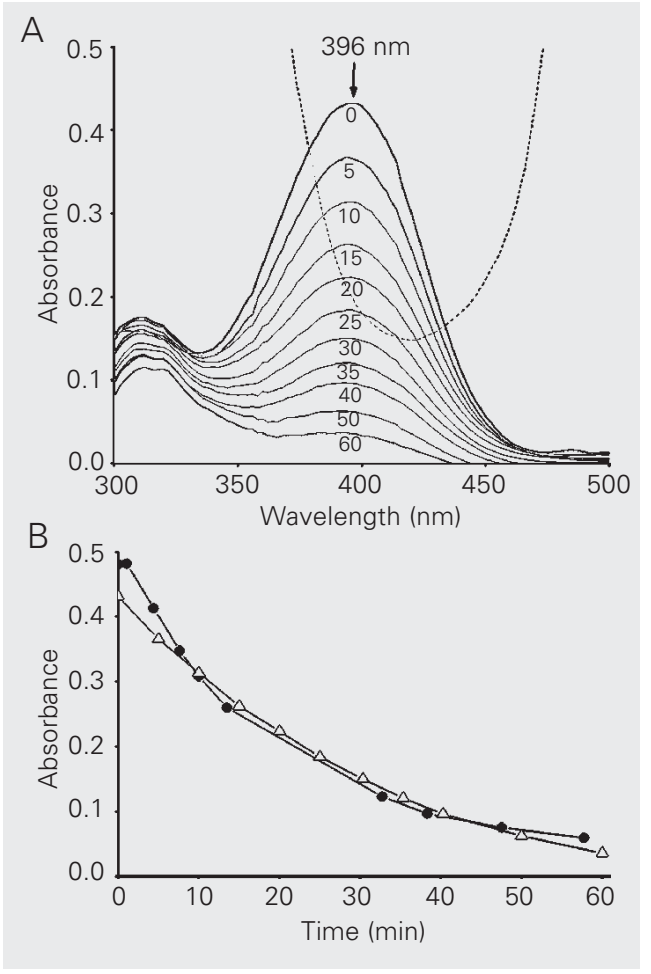

performed by the Student $t$-test. The Tukey test with a $95 \%$ confidence interval was applied to compare the means. The statistical analyses were done using the InStat software program for Windows (GraphPads software, San Diego, CA, USA).

\section{Results and Discussion}

The results presented in Figure 2 show the effect of illumination on Quinifuryl toxicity to P388 cells which was measured by both dye (TB) exclusion and dye (MTT) inclusion methods. A significantly elevated toxic effect of Quinifuryl on P388 cells was observed under illumination of the incubation mixture with visible light (390-500 nm). A $20 \mu \mathrm{M}$ Quinifuryl concentration caused death of $50 \%$ of cells after 26 min (dye inclusion method) or $32.5 \mathrm{~min}$ (dye exclusion method) of illumination, and $>80 \%$ of cells died after $60 \mathrm{~min}$ of illumination. The toxicity observed for 60-min illumination in the absence of Quinifuryl (Figure 2, curve $\mathrm{C} 1)$ or in the presence of Quinifuryl in the dark (Figure 2, curve C2) was $<10 \%$ of that observed under illumination in the presence of Quinifuryl.

The photocytotoxic effect of Quinifuryl under irradiation was accompanied by photodecomposition of Quinifuryl (Figure 3A) that was monitored by a decrease of the specific absorption of the compound at $396 \mathrm{~nm}\left(\varepsilon_{396}=\right.$ $2.47 \times 10^{4} \mathrm{M}^{-1} \mathrm{~cm}^{-1}$; Ref. 18). The presence of P388 cells did not alter the dynamics of Quinifuryl photobleaching (Figure 3B).

The photocytotoxic effect of Quinifuryl was further investigated in a series of experiments with different Quinifuryl concentrations performed using the MTT inclusion method (test 2). The time dependence of the toxic effect of Quinifuryl on P388 cells shows that the drug cytotoxicity in the dark was significantly reduced compared to the photocytotoxicity over the range of drug concentrations from 0.2 to $20 \mu \mathrm{M}$ (Figure 4). According to these data, the $\mathrm{TE}_{\mathrm{L}} / \mathrm{TE}_{\mathrm{D}}$ ratios 
(toxic effects under illumination and in the dark, respectively) after 60 min of drug incubation with cells were $6.6 \pm 1.4,2.4 \pm 0.7$, and $9.9 \pm 2.4$ at initial Quinifuryl concentrations of $0.2,2.0$, and $20.0 \mu \mathrm{M}$, respectively.

The $\mathrm{LC}_{50}$ values estimated from the drug concentration dependence of the toxic effect
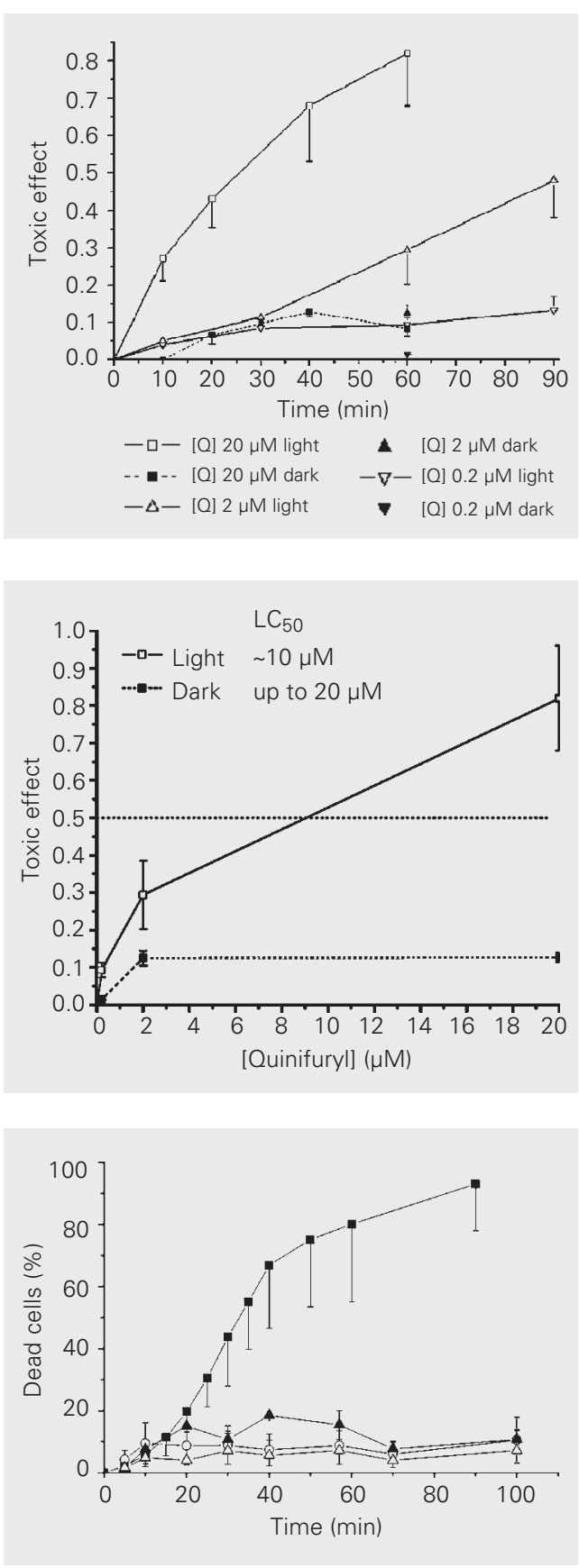

(Figure 5) confirmed the above conclusion that the Quinifuryl toxicity was much higher under illumination than in the dark. Indeed, for 60 min of cell incubation with Quinifuryl under illumination, the death of $50 \%$ of the cells was observed with the drug concentration of $10 \mu \mathrm{M}$, while cell incubation with up
Figure 4. Time dependence of the toxic effect of Quinifuryl [Q] on P388 cells measured in the dark (filled symbols) and under illumination with visible light (390$500 \mathrm{~nm}$ ) (open symbols). Initial drug concentrations were: $0.2 \mu \mathrm{M}$ (inverted triangles), $2 \mu \mathrm{M}$ (triangles), and $20 \mu \mathrm{M}$ (squares). Experiments were performed in 96well ELISA-type plates $\left(2 \times 10^{4}\right.$ cells/well) by dye (MTT) inclusion methods (for further details, see test 2 in Material and Methods). TE $=[\mathrm{DC}] /[\text { Cell] }]^{\text {control, }}$ where TE is toxic effect, [Cell]control is cell concentration in control wells (cells incubated for the same period of time with no compound) and [DC] is the dead cell concentration. Each point indicates the mean \pm SD of 6 measurements.

Figure 5. LC 50 estimation: the concentration dependence of the toxic effect of Quinifuryl on P388 cells measured in the dark (dashed line, filled squares) and under illumination with visible light $(390-500 \mathrm{~nm}$; solid line, open squares). The time of drug incubation with cells was $60 \mathrm{~min}$. Experiments were performed and toxic effect values calculated as described in the legend to Figure 4. The LC 50 was estimated as $100 \times$ ( $\mathrm{T}^{0}$. $\mathrm{T}) / \mathrm{T}^{0}=50$, where $\mathrm{T}^{0}$ and $\mathrm{T}$ are the absorbances of the test well at time zero (when the compound is added) and after exposure to Quinifuryl. Conditions of illumination were the same as described in the legend to Figure 2. Each point represents the mean $\pm S D$ of 6 measurements.

Figure 6. Cytotoxicity of Quinifuryl (filled symbols) and final products of its photodecomposition (open symbols) to mouse leukemia P388 cells in the dark (open circles, filled triangles) and under illumination (filled squares, open triangles) as measured by the dye exclusion method (Trypan blue; test 1, Material and Methods). Cell concentration was $\sim 5 \times 10^{4}$ in sodium phosphate buffer, and Quinifuryl concentration was $2 \mu \mathrm{M}$, $\mathrm{pH}$ 7.4. Each point represents the mean \pm SD of 3 measurements. 
to $20 \mu \mathrm{M}$ Quinifuryl for the same period of time in the dark caused the death of no more than $15 \%$ of cells.

In contrast to test 2 that indicated only the killing effect of the drug, test 3 revealed the complete cytotoxicity that included cell proliferation arrest. The results obtained using this method are presented in Table 2, along with the data obtained using test 2 (the killing effect of Quinifuryl). These data show that Quinifuryl not only caused death, but also attenuated the proliferation of the surviving P388 cells. Both effects were significantly enhanced under illumination. A further conclusion from these data is that the toxic effect of Quinifuryl on P388 cells is due to cell proliferation arrest rather than to cell death.

The cell survival test (test 1, Material and Methods) was employed to determine whether the final products of Quinifuryl photodecomposition might be responsible for the elevated toxicity of this drug under illumination. For this reason, $\mathrm{P} 388$ cells $\left(5 \times 10^{4}\right.$ cells $\left./ \mathrm{ml}\right)$ were incubated for up to $100 \mathrm{~min}$ with either Quinifuryl (at a final concentration of $2 \mu \mathrm{M}$ ) or final products of photodecomposition of the drug. In the latter case, the $18 \mu \mathrm{M}$ Quinifuryl solution was illuminated until the major

Table 2. Toxic effects (test 2) and post-effects (test 3 ) of Quinifuryl on P388 cells after 60 min of incubation with cells either in the dark or under illumination with visible light (390-500 nm).

\begin{tabular}{lccccc}
\hline Quinifuryl $(\mu \mathrm{M})$ & \multicolumn{4}{c}{ Toxic effect } \\
\cline { 2 - 3 } & \multicolumn{3}{c}{ Dark } & & \multicolumn{2}{c}{ Illumination } \\
\cline { 2 - 3 } \cline { 5 - 6 } & Test 2 & Test 3 & & Test 2 & Test 3 \\
\hline 0.2 & $0.014 \pm 0.002$ & $0.62 \pm 0.11$ & & $0.09 \pm 0.02$ & $0.99 \pm 0.005$ \\
2 & $0.12 \pm 0.02$ & $0.91 \pm 0.08^{*}$ & & $0.29 \pm 0.09$ & $0.96 \pm 0.008^{*}$
\end{tabular}

Post-effects were measured $52 \mathrm{~h}$ after drug removal from the cell culture. Toxic effects (TE) were measured using the MTT assay and calculated as: TE $=[D C] /$

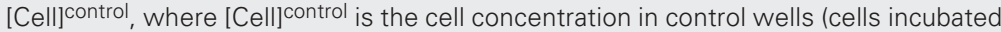
for the same period of time without the drug) and [DC] is the dead cell concentration. $[D C]$ is calculated as [Cell] $]^{\text {control }}$ - [Cell] ${ }^{\text {final }}$, where [Cell] ${ }^{\text {final }}$ is the live cell concentration in wells exposed to drug. [DC] was measured either immediately after drug removal (test 2) or after cell incubation with fresh medium for $52 \mathrm{~h}$ (test 3). For further details, see Material and Methods.

${ }^{*} \mathrm{P}<0.01$ for comparison between the appropriate data obtained in the dark and under illumination (Tukey test).
Quinifuryl peak at $396 \mathrm{~nm}$ disappeared (see Figure 3A). Then, cells were added to a postphotolysis mixture and incubated in the dark. The results presented in Figure 6 show that the final products of Quinifuryl photodecomposition as well as Quinifuryl itself had low toxicity in the dark, causing death of less than $10 \%$ cells at $100 \mathrm{~min}$ of incubation. The final products of Quinifuryl were also non-toxic under 60-min illumination, while Quinifuryl itself caused death of nearly $90 \%$ of the cells. These results clearly show that the final products of Quinifuryl photodecomposition are not responsible for the cytotoxicity of this drug.

Based on the data presented above, it seems that the detailed mechanisms of photocytotoxicity of Quinifuryl deserve special investigation. The observation that the photoactivation of Quinifuryl significantly accelerates cell killing, along with the observation that the final products of Quinifuryl photolysis are not responsible for this acceleration, should be interpreted as evidence that more toxic short-lived intermediates are formed during photolysis. Evidence of the formation of reactive species during Quinifuryl photolysis by visible light was reported in our previous studies $(13,18)$. The formation of the triplet excited state of the drug molecule was observed (13), which is capable of producing singlet oxygen $(19,20)$. We had also detected the reactions of the triplet state with the drug in the ground state and with electron donors $(13,21)$, with the formation of superoxide anion radical (18). The formation of reactive oxygen species in the course of Quinifuryl photolysis may be responsible for the photocytotoxicity of the drug. However, the possible toxicity of shortlived intermediates of Quinifuryl decomposition should be further investigated.

To the best of our knowledge, the data presented here are the first to indicate photocytotoxicity of a nitroheterocyclic compound and demonstrate the possibility of its application as a photosensitizer drug for photochemotherapy. 


\section{References}

1. Dougherty TJ (1993). Photodynamic therapy. Photochemistry and Photobiology, 58: 895-900.

2. Ochsner M (1997). Photophysical and photobiological processes in the photodynamic therapy of tumours. Journal of Photochemistry and Photobiology. B, Biology, 39: 1-18.

3. Sobolev AS, Jans DA \& Rosenkranz AA (2000). Targeted intracellular delivery of photosensitizers. Progress in Biophysics and Molecular Biology, 73: 51-90.

4. Franck B \& Nonn A (1995). Novel porphyrinoids for chemistry and medicine by biomimetic syntheses. Angewandte Chemie (International Edition, English), 34: 1795-1811.

5. Oertel M, Schastak SI, Tannapfel A, Hermann R, Sack U, Mossner J \& Berr F (2003). Novel bacteriochlorine for high tissue-penetration: photodynamic properties in human biliary tract cancer cells in vitro and in mouse tumour model. Journal of Photochemistry and Photobiology. B, Biology, 71: 1-10.

6. Bourre L, Simonneaux G, Ferrand $Y$, Thibaut $S$, Lajat $Y$ \& Patrice $T$ (2003). Synthesis, and in vitro and in vivo evaluation of a diphenylchlorin sensitizer for photodynamic therapy. Journal of Photochemistry and Photobiology. B, Biology, 69: 179-192.

7. Kassab K (2002). Photophysical and photosensitizing properties of selected cyanines. Journal of Photochemistry and Photobiology. B, Biology, 68: 15-22.

8. Dobrucki JW (2001). Interaction of oxygen-sensitive luminescent probes Ru(phen)32+ and Ru(bipy)32+ with animal and plant cells in vitro: Mechanism of phototoxicity and conditions for non-invasive oxygen measurements. Journal of Photochemistry and Photobiology. B, Biology, 65: 136-144.

9. Bohm F, Edge R, Foley S, Lange L \& Truscott TG (2002). Antioxidant inhibition of porphyrin-induced cellular phototoxicity. Journal of Photochemistry and Photobiology. B, Biology, 65: 177-183.

10. Verovskiy VN, Degterev IA, Sukhova NM, Buzukov AA, Leonova EYu \& Tatarskaya NK (1990). Interrelation between structure, microsomal metabolizing activation, mouse toxicity, cytotoxicity and antitumor activity of heterocyclic and nitroheterocyclic compounds. In vitro and in vivo study. Pharmaceutical Chemistry Journal, 24: 2024.

11. Rossa MM, Rocha-e-Silva TAA, Terruggi CHB, Tedesco AC, Selistre-
de-Araujo HS, Borissevich IE \& Degterev IA (2003). Comparison of the cytotoxicity of two nitroheterocyclic drugs (NHCD) towards transformed and non-transformed cells. Pharmaceutical Research, 48: 369-375.

12. Voronina SS, Tatarskaya NK, Degterev IA, Serebrianiy AM, Pelevina II \& Sukhova NM (1985). Radiosensitizing activity and metabolism of some nitrofuran derivatives. Radiobiology, 25: 748-751.

13. Borissevich YE, Daghastanli NA \& Degterev IA (2003). Primary processes of photodecomposition of 2-(5'-nitro-2'-furanyl)ethenyl4-\{N-[4'-(N,N-diethylamino)-1'-methylbutyl]carbamoyl\} quinoline. Effect of oxygen and compound concentration. Journal of Photochemistry and Photobiology. A, Chemistry, 159: 213-217.

14. Kochevar IE, Lambert CR, Lynch MC \& Tedesco AC (1996). Comparison of photosensitized plasma membrane damage caused by singlet oxygen and free radicals. Biochimica et Biophysica Acta, 1280: 223-230.

15. Kaltenbach JP, Kaltenbach MH \& Lyons WB (1958). Nigrosin as a dye for differentiating live and dead ascites cells. Experimental Cell Research, 15: 112-117.

16. Mosmann T (1983). Rapid colorimetric assay for cellular growth and survival: application to proliferation and cytotoxicity assays. Journal of Immunological Methods, 65: 55-63.

17. Monks A, Scudiero D, Skehan P, Shoemaker R, Paull K, Vistica D, Hose C, Langley J, Cronise P \& Vaigro-Wolff A (1991). Feasibility of a high-flux anticancer drug screen using a diverse panel of cultured human tumor cell lines. Journal of the National Cancer Institute, 83: 757-766.

18. Smirnov SM, Jurav MA, Tatarskaja NK, Borisevich YE \& Degterev IA (1989). Quinifur photoreduction and nitroanion radical formation. Chemical Physics, 8: 1723-1725.

19. Moan J \& Berg K (1992). Photochemotherapy of cancer: experimental research. Photochemistry and Photobiology, 55: 931-948.

20. Henderson BW \& Dougerthy TR (1992). How does photodynamic therapy work? Photochemistry and Photobiology, 55: 145-157.

21. Kuzmin VA, Levin PP, Borisevich YE, Degterev IA \& Smirnov SM (1988). Triplet exciplex of nitrofuran derivative with aromatic amines. Proceedings of the Academy of Sciences of the USSR, Chemistry, 7: 1510-1514. 